\title{
CHARACTERISTICS OF COMPOST FROM BALINESE CATTLE DUNG (CD) AND RICE STRAW (RS) USING WHITE ROT FUNGUS (Wrf) (Ganoderma sp) AS BIOACTIVATORS
}

\author{
Muhammad Irfan Said ${ }^{* 1)}$, Jamila Mustabi ${ }^{2)}$, Siti Amelia Putri Syamsuddin ${ }^{3)}$ \\ 1,3) Department of Animal Production, Faculty of Animal Science, Hasanuddin University, Tamalanrea Indah, \\ Kec. Tamalanrea, Makassar City, South Sulawesi, Indonesia, 90245 \\ 2) Department of Animal Feed and Nutrition, Faculty of Animal Science, Hasanuddin University, Tamalanrea \\ Indah, Kec. Tamalanrea, Makassar City, South Sulawesi, Indonesia, 90245 \\ E-mail: irfan.said@unhas.ac.id
}

Submitted 4 August 2020; Accepted 3 September 2020

\begin{abstract}
To maximize the performance of the fermentation process, there is a need for a biactivator. The purpose of this study was to evaluate the characteristics of compost-based waste from cattle dung (CD) combined with rice straw (RS) by applying white rot fungus (Wrf) (Ganoderma $s p$ ) as a bioactivator. In this study, 6 types of treatments have been applied, namely $\mathrm{T}_{1}(\mathrm{CD}: \mathrm{RS})(25 \%: 75 \%)+5 \%$ of $\mathrm{Wrf} ; \quad \mathrm{T}_{2}(\mathrm{CD}: \mathrm{RS})(50 \%: 50 \%)+5 \%$ of $\mathrm{Wrf}$; $\mathrm{T}_{3}(\mathrm{CD}: \mathrm{RS})(75 \%: 25 \%)+5 \%$ of $\mathrm{Wrf} ; \quad \mathrm{T}_{4} \quad(\mathrm{CD}: \mathrm{RS})(25 \%: 25 \%)+0 \%$ of $\mathrm{Wrf}$; $\mathrm{T}_{5}(\mathrm{CD}: \mathrm{RS})(50 \%: 50 \%)+0 \%$ of $\mathrm{Wrf} ; \mathrm{T}_{6}(\mathrm{CD}: \mathrm{RS})(75 \%: 25 \%)+0 \%$ of Wrf. The study was designed experimentally using a completely randomized design (CRD), 6 treatments with 3 replications. Based on the research results, the difference in the ratio of $\mathrm{CD}$ to $\mathrm{RS}$ and the use of Wrf bioactivator has a significant effect $(\mathrm{p}<0.05)$ in increasing the $\mathrm{pH}$, temperature, $\mathrm{C}$ organic and $\mathrm{C} / \mathrm{N}$ ratio in compost. However, this difference had no significant effect $(\mathrm{p}>0.05)$ on the $\mathrm{C}$-organic value. The $\mathrm{pH}$ value of compost was obtained with variations of $5.50 \pm 0.43$ $6.73 \pm 0.06$. Temperature of compost is in the range of values $24.00 \pm 0.00-25.67 \pm 0.58{ }^{\circ} \mathrm{C}$. The $\mathrm{C}$-organic value is in the range of $24.38 \pm 0.48-31.32 \pm 0.80 \%$, while the $\mathrm{N}$-organic value varies at $1.34 \pm 0.11-2.10 \pm 0.15 \%$. The $\mathrm{C} / \mathrm{N}$ ratio is in the range of $15.00 \pm 0.11-19.33 \pm 1.15$. Based on the interaction, the results showed that there was a significant interaction $(\mathrm{p}>0.05)$ between the use of Wrf bioactivator with the ratio of $\mathrm{CD}$ to $\mathrm{RS}$ on the parameters of $\mathrm{pH}, \mathrm{N}$-organic and $\mathrm{C} /$ Nratio, while, C-organic and temperature had no significant effect. The results of the study was concluded that several test parameters produced compost characteristics that were in accordance with Standar Nasional Indonesia (SNI) and the Regulation of the Minister of Agriculture of the Republic of Indonesia. Compost production using $\mathrm{T}_{3}$ treatment $((\mathrm{CD}: \mathrm{RS})(75 \%: 25 \%)+5 \%$ of $\mathrm{Wrf})$ produces the best characteristics compared to other treatments.
\end{abstract}

Keywords: Compost; cattle dung; rice straw; white rot fungus; bioactivators 


\section{INTRODUCTION}

Compost is one type of organic fertilizer as a result of breaking down living organisms (animals or plants) with the help of organisms (bioactivators). The need for compost has increased every year with the increasing need for food by humans. The compost production process is one of the efforts made to reduce waste production, especially solid waste) (Neugebauer and Sołowiej, 2017; Pandey et al., 2016; Proietti et al., 2016). Compost fertilizer production is one solution to reduce the use of artificial fertilizers (chemical fertilizers). Compost can increase the availability of nutrients that have a positive impact on the soil and plants (Milinković et al., 2019). The use of chemical fertilizers has been applied by the world community since the start of the green revolution movement (Leita et al., 1999). The use of chemical fertilizers has a negative impact on the process of soil degradation and an increase in the process of soil pollution. This certainly has an impact on groundwater quality (Kaur et al., 2008; Chaudhry et al., 2009). In addition, the application of chemical fertilizers will have a very large impact on environmental sustainability (Akdeniz, 2019; Morari et al., 2011).

The composting process is one of the technologies that has been widely applied in reducing solid waste, especially biomass. This process is one of the most important steps to support the supply of organic fertilizer for agricultural land needs (Neugebauer et al., 2017; Pandey et al., 2016; Proietti et al., 2016). Mature compost will reduce the rate of heating, the thermophilic process, peak temperature and the rate of solid degradation. Adding mature compost may increase the cellulase, peroxidase, arilsulfatase, and urease content during the mesophilic phase, and increase the urease content. During the cooling phase, it can however decrease cellulase, peroxidase, protease, and arilsulfatase (Ma et al., 2019).

Utilization of waste from agriculture and livestock has been widely applied in the process of making compost. One type of livestock waste that can be developed as raw material for compost is cow dung (Said, 2014). To improve compost quality, bioactivators are needed as decomposing microorganisms. Balinese cattle is one of the many local cattle developed in Indonesia. In fact, the population of Balinese cattle dominates from the entire population of cattle in Indonesia. Baline cattle population is estimated at 560,546 heads (Republika, 2020). Average dung production in beef cattle is in the range of $20 \mathrm{~kg} / \mathrm{head} / \mathrm{d}$ (Saputro et al., 2014). This amount is also likely to be owned by Balinese cattle. Based on these data, it can be projected that the amount of dung production will reach $11,210,920 \mathrm{~kg}$ or equivalent to $11,210.92$ tons/d.

White rot fungus (Wrf) (Ganoderma $s p$ ) is one of the biactivators that can be used as decomposers in the process of making compost. White rot fungus is one of the decomposing organisms that has able to degrade lignin and polysaccharide compounds well (Hsu and Buckley, 2008; Philippot et al., 2011). White rot fungus (Wrf) was an organism of the fungus type that was able to degrade wood lignin compounds. The quality of compost were influenced by the ratio of the use of raw materials. To produce quality compost, the right material ratio and the role of bioactivators during the process are needed. This study aims to evaluate the

How to cite:

Said, M. I., Mustabi, J., \& Syamsuddin, S. A. P. (2020). Characteristics of Compost from Balinese Cattle Dung (CD) and Rice Straw (RS) using White Rot Fungus (Wrf) (Ganoderma sp) As Bioactivators. Jurnal Ilmu dan Teknologi Hasil Ternak, 15 (3), 194204 
characteristics of compost using a combination of cow dung (CD) with rice straw (RS) at different ratios and the role of bioactivators.

\section{MATERIALS AND METHODS}

\section{Materials}

In this study, the main materials were waste from cattle dung (CD), rice straw (RS) and Wrf (Ganoderma $s p$ ) bioactivator. The $\mathrm{CD}$ were obtained from Balinese cattle at the Beef Cattle Laboratory, Faculty of Animal Science, Hasanuddin University, Makassar, Indonesia. The RS were obtained from fields in Makassar City, Indonesia. The Wrf bioactivators were obtained from the Waste and Biomass Valorization Laboratory, Faculty of Animal Science, Hasanuddin
University, Makassar, Indonesia. Some supporting equipment used were scale, pan, bucket, thermometer and $\mathrm{pH}$ meters.

\section{Methods \\ Pretreatment}

The raw material (CD and $\mathrm{RS}$ ) were prepared $9 \mathrm{~kg}$ each. First of all, all the raw materials have been pasteurized using a steaming pan at $80^{\circ} \mathrm{C}$ for $15 \mathrm{~min}$. Wrf (Ganoderma sp) bioactivators were prepared in the form of powder products.

\section{Formulation material of compost}

The pasteurized raw materials (CD and RS) were cooled at room temperature. The raw materials ( $\mathrm{CD}$ and $\mathrm{RS}$ ) were then ground to reduce particle size. The formula for compost and biactivator was then arranged as in Table 1 .

Table 1. The composition of the materials used in making compost from each treatment

\begin{tabular}{ccccccc}
\hline \multirow{2}{*}{ Materials } & \multicolumn{5}{c}{ Treatments } \\
\cline { 2 - 7 } & $\mathrm{T}_{1}$ & $\mathrm{~T}_{2}$ & $\mathrm{~T}_{3}$ & $\mathrm{~T}_{4}$ & $\mathrm{~T}_{5}$ & $\mathrm{~T}_{6}$ \\
\hline \multirow{2}{*}{ Cattle Dung (CD) (g) } & 250 & 500 & 750 & 250 & 500 & 750 \\
& $(25 \%)$ & $(50 \%)$ & $(75 \%)$ & $(25 \%)$ & $(50 \%)$ & $(75 \%)$ \\
Rice Straw (RS) (g) & 750 & 500 & 250 & 750 & 500 & 250 \\
Wrf (Ganoderma sp) & $(75 \%)$ & $(50 \%)$ & $(25 \%)$ & $(75 \%)$ & $(50 \%)$ & $(25 \%)$ \\
Bioactivator (g) & 50 & 50 & 50 & 0 & 0 & 0 \\
\hline
\end{tabular}

\section{Fermentation process}

The packaging used in making compost was a polybag clear plastic (HDPE) $15 \times 20 \mathrm{~cm}$ size. The number of polybag prepared was 18 pieces. This amount is in accordance with the number of treatment units that have been applied (6 treatments and 3 replications). The raw materials (CD and RS) were put into polybag clear plastic, respectively according to the formula in Table 1. The fermentation process was carried out for $30 \mathrm{ds}$. The fermentation process was carried out semi-aerobically.

\section{Methods of determining variables}

- Temperature. Temperature was measured using a thermometer. The electrode part of the thermometer was put into compost and then the measurement results will be read.
- $\mathrm{pH}$ value (Agus, 2005). A total of $100 \mathrm{~g}$ of compost sample was taken from 3 points in the compost heap. The $\mathrm{pH}$ meter was calibrated to validate the test results using a buffer of $\mathrm{pH} 7.0$ and $\mathrm{pH} 4.0$. The tip of the electrode was inserted into the sample and then the results were read.

- C-organic (Agus, 2005). Compost fertilizer samples $(50 \mathrm{~g})$ were put into $100 \mathrm{ml}$ volumetric flasks. Subsequent samples were added with $\mathrm{K}_{2} \mathrm{Cr}_{2} \mathrm{O}_{7} 2 \mathrm{~N}$ (5 mL) and $\mathrm{H}_{2} \mathrm{SO}_{4} 98 \%$ (p.a) (7 mL). The mixture was homogenized by shaking. The mixture was allowed to stand for 30 min. A standard $250 \mathrm{ppm} \mathrm{C}$ solution was prepared. A standard solution of $5000 \mathrm{ppm}(5 \mathrm{~mL})$ was put into a volumetric flask $(100 \mathrm{~mL})$. The flask was added with a solution of $\mathrm{H}_{2} \mathrm{SO}_{4}+$ $\mathrm{K}_{2} \mathrm{Cr}_{2} \mathrm{O}_{7} 2 \mathrm{~N}$ solution each of $5 \mathrm{~mL}$ and 
$7 \mathrm{~mL}$ (as in the previous process). A standard solution ( $0 \mathrm{ppm} \mathrm{C}$ ) was used as a standard solution. Each sample was diluted with aquadest. A total of $100 \mathrm{~mL}$ was then shaken until homogeneous and allowed to stand for 1 night. The results were measured by spectrophotometer at $\lambda$ $=651 \eta \mathrm{m}$. C-organic $(\%)=$ ppm curve $\mathrm{x}$ $100 / \mathrm{mg}$ sample $\mathrm{x} \mathrm{Fk}$, where ppm curve $=$ standard regression curve; $\mathrm{Fk}=$ correction factor for water content $=$ $100 /(100$-\% water content).

- N-organic (Agus, 2005). A total of $5 \mathrm{mg}$ of compost sample was put into the Kjeldahl flask, added 0.25-0.50g selenium mixture $+3 \mathrm{~mL} \mathrm{H}_{2} \mathrm{SO}_{4}$ (p.a). The solution was homogenized by shaking. The mixture was allowed to stand for 2-3 h. The solution was then processed for 3-3.5 $\mathrm{h}$ on a hotplate (150$350{ }^{\circ} \mathrm{C}$ ). The process was carried out in stages until a clear solution was obtained. The solution was cooled and diluted. The solution was transferred to a volumetric flask $(250 \mathrm{~mL})$. In the volumetric flask, then adding aquadest to half the volume of the volumetric flask. The boiling stone was put into a volumetric flask. A total of $10 \mathrm{~mL}$ of $1 \%$ boric acid as a distillate reservoir was prepared in Erlenmeyer $(100 \mathrm{~mL})$. The solution was given with 3 drops of the Conway indicator. The distillation process was carried out by adding $20 \mathrm{~mL}$ of $40 \% \mathrm{NaOH}$ solution. This process was completed when the volume of liquid in Erlenmeyer has reached $75 \mathrm{~mL}$. The distillation results were titrated with $\mathrm{H}_{2} \mathrm{SO}_{4} 0.05 \mathrm{~N}$, to the end point (the color of the solution changes from green to pink) $=\mathrm{A} \mathrm{mL}$, while the determination of blanks = A1 $\mathrm{mL}$. The formula used, $\mathrm{N}$-organic $=$ total titration blank $(\mathrm{mL})$ - titration sample $\mathrm{x} N$ $\mathrm{x}$ BST N / sample weight $(\mathrm{mg}) \mathrm{x} 100$, where $\mathrm{BST} \mathrm{N}=$ nitrogen equivalent weight.

- $\mathrm{C} / \mathrm{N}$ ratio (Agus, 2005). Determination of the value of the $\mathrm{C} / \mathrm{N}$ ratio was done by comparing the value of $\mathrm{C}$-organic with
$\mathrm{N}$-organic. The formula was used, $\mathrm{C} / \mathrm{N}$ ratio $=\mathrm{C}$-organic value $/ \mathrm{N}$-organic value .

\section{Research Design and Data Analysis}

A completely randomized design (CRD) 6x3 Unidirectional Patterns has been applied in this research. The six treatments were applied $\mathrm{T}_{1}(\mathrm{CD}: \mathrm{RS})(25 \%: 75 \%)+5 \%$ of Wrf; $\mathrm{T}_{2}$ (CD:RS)(50\%:50\%) $+5 \%$ of Wrf; $\mathrm{T}_{3}(\mathrm{CD}: \mathrm{RS})(75 \%: 25 \%)+5 \%$ of $\mathrm{Wrf}$; $\mathrm{T}_{4}(\mathrm{CD}: \mathrm{RS})(25 \%: 25 \%)+0 \%$ of Wrf; $\mathrm{T}_{5}$ $(\mathrm{CD}: \mathrm{RS})(50 \%: 50 \%)+0 \%$ of Wrf; $\mathrm{T}_{6}$ $(\mathrm{CD}: \mathrm{RS})(75 \%: 25 \%)+0 \%$ of Wrf. Each treatment was repeated three times.

The research data were analyzed using ANOVA by the SPSS statistical program. Treatments that show a significant effect, then a significant difference test with Duncan's Multiple Range Test (DMRT) was performed at a level of 5\% (Steel and Torrie, 1991).

\section{RESULTS AND DISCUSSION}

\section{Temperature}

Temperature is one of the important parameters for the fermentation process of organic matter. Temperature changes can be used as an indicator of the fermentation process. The different temperature values of each treatment were presented in Figure 1.

Based of ANOVA on the data (Figure 1), statistically, shows that the use of raw materials with different ratios (CD and RS) in the compost fermentation process has a very significant effect $(p<0.01)$ on changes in fermentation temperature. However, the application of different bioactivators and their interactions did not affect ( $p>0.05)$ to the rate of temperature change during the fermentation process. The recorded temperature was the final temperature of the composting process. In general, the temperature was obtained in the range of $24.00 \pm 1.00-25.67 \pm 0.58^{\circ} \mathrm{C}$.

The difference in the material ratio significantly increases the fermentation temperature. This is caused by the degradation ability of microorganisms that are different from each ingredient. An 
increase in the ratio of $\mathrm{CD}$ usage has a positive correlation with an increase in fermentation temperature. This might be due to an increase in the amount of organic matter so that bacterial activity also increases. Increasing the amount of organic matter will increase the rate of bacterial degradation.

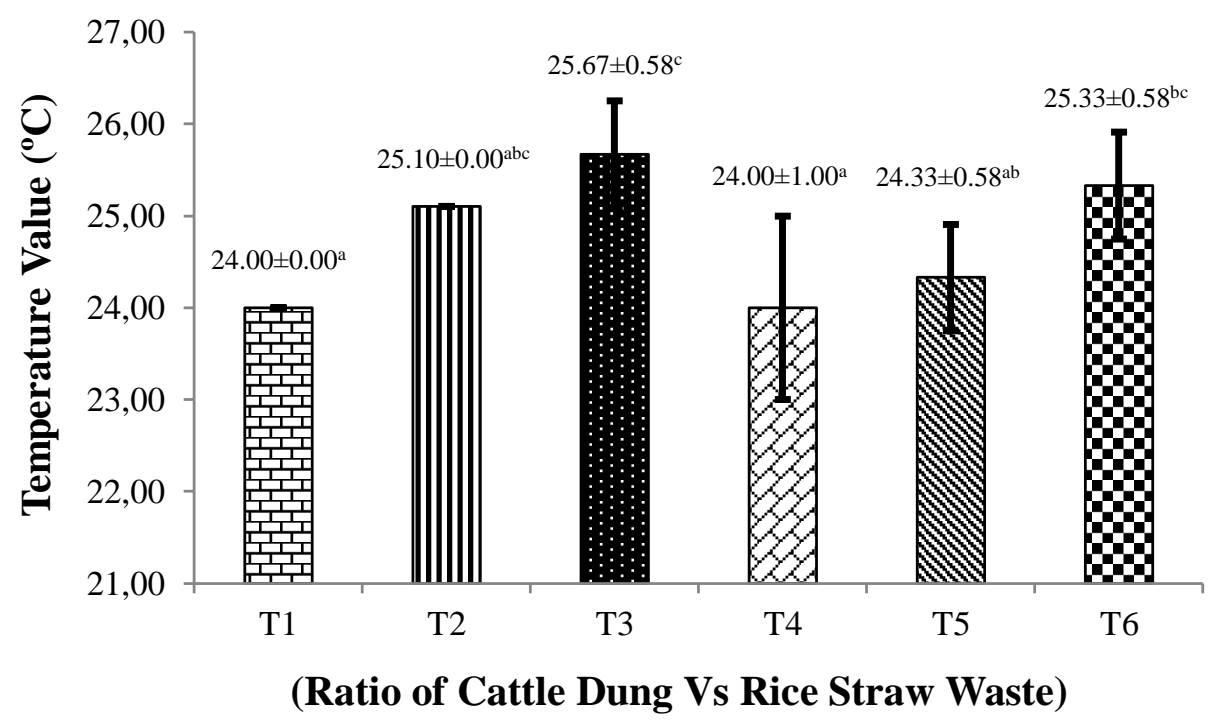

Figure 1. Comparison of temperature values of compost in various treatment ratios of materials and Wrf (Ganoderma sp) bioactivator application. $\mathrm{T}_{1}$ (CD:RS)(25\%:75\%)+5\% of Wrf; $\mathrm{T}_{2}(\mathrm{CD}: \mathrm{RS})(50 \%: 50 \%)+5 \%$ of Wrf; $\mathrm{T}_{3}(\mathrm{CD}: \mathrm{RS})(75 \%: 25 \%)+5 \%$ of Wrf; $\mathrm{T}_{4}$ $(\mathrm{CD}: \mathrm{RS})(25 \%: 25 \%)+0 \%$ of $\mathrm{Wrf} ; \mathrm{T}_{5}$ (CD:RS)(50\%:50\%)+0\% of Wrf; $\mathrm{T}_{6}$ (CD:RS)(75\%:25\%)+0\% of Wrf; a,b,c Different superscripts show significant differences $(\mathrm{p}<0.05)$; Fermentation time $=30 \mathrm{ds} ; \mathrm{CD}=$ Cow Dung; RS =Rice Straw; $\mathrm{Wrf}=$ White rot fungus (Ganoderma $s p)$

This will spur an increase in fermentation temperature (Zhu et al., 2019). The composting process can reach temperatures of $60^{\circ} \mathrm{C}$. This temperature can activate pathogenic bacteria, viruses and worm eggs. The composting process is divided into 4 stages, namely: 1) mesophyll stage with a temperature of $30-40{ }^{\circ} \mathrm{C}$, furthermore 2) the thermophile stage increased 50-70 ${ }^{\circ} \mathrm{C}$, then 3 ) the cooking stage with temperatures $30-40{ }^{\circ} \mathrm{C}$ and 4 ) the cooling stage with temperatures $<40{ }^{\circ} \mathrm{C}$. The composting process that requires high temperatures is at the thermophile stage.

At this stage the population of mesophyll organisms decreases and the degradation of organic matter becomes high by the activity of thermophilic microorganisms. Environmental $\mathrm{pH}$ has increased ( $>7$ ) due to protein deamination to produce alkaline ammonia. At this stage microorganisms (fungi) will secrete extracellular enzymes that will break down polymer compounds such as cellulose and complex carbohydrates. In this regard, the measured temperature of $25^{\circ} \mathrm{C}$ is the temperature data obtained in step (4), which is the cooling process. During the cooling process the compost temperature has dropped to $<40^{\circ} \mathrm{C}$.

The activity of mesophilic microorganisms is reactivated and the environmental $\mathrm{pH}$ gradually decreases. Nitrified bacteria that are inhibited at high temperatures will convert ammonia to nitrate so that the $\mathrm{pH}$ of the compost has decreased to near neutral $\mathrm{pH}$ (Said, 2014). The Wrf bioactivator was used to help the process of degradation of natural microorganisms that already exist in the material to degrade the components of organic material. 


\section{pH Value}

The $\mathrm{pH}$ value plays an important role in the composting process. Acidic conditions in a media affect the activity of microorganisms (Zhang et al., 2016). Changes in $\mathrm{pH}$ in compost were influenced by the production of organic acids carried out by microorganisms as bioactivators. The characteristics of compost $\mathrm{pH}$ at various different raw material ratios (CD and $\mathrm{RS}$ ) were presented in Figure 1.

Based on the analysis of variance (ANOVA) (Figure 2) shows that the application of bioactivators in the process of making compost has a significant effect $(\mathrm{p}<0.05)$ on the $\mathrm{pH}$ parameters. However, the difference in the ratio of $\mathrm{CD}$ and $\mathrm{RS}$ did not show any significant effect ( $p>0.05)$. In general, it was seen that the $\mathrm{pH}$ value of each treatment varied considerably $(5.50 \pm 0.43$ $6.73 \pm 0.04)$. This value is still in acidic to neutral conditions. A low $\mathrm{pH}$ value (acid) can occur by the presence of Wrf (Ganoderma sp) microorganisms as bioactivators. Bioactivator activity is carried out through the fermentation process to produce acid. The $\mathrm{pH}$ value of compost by Mao et al. (2018) and Chen et al. (2017a) (2017b) is still higher than the $\mathrm{pH}$ value of the compost produced (7.5-7.8 and 8.1). This difference can be caused by the raw material and the type of bioactivator used. Where, the research conducted using biochar raw materials (corn stalks, bamboo, wood, manure, and coir). Increased oxygen consumption by microorganisms as bioactivators can cause high $\mathrm{pH}$ values. High $\mathrm{pH}$ values will provide a bad environment for activities other organics, however, a low $\mathrm{pH}$ value might be a cause of death in microorganisms (bioactivators) (Ratzke \& Gore, 2018)

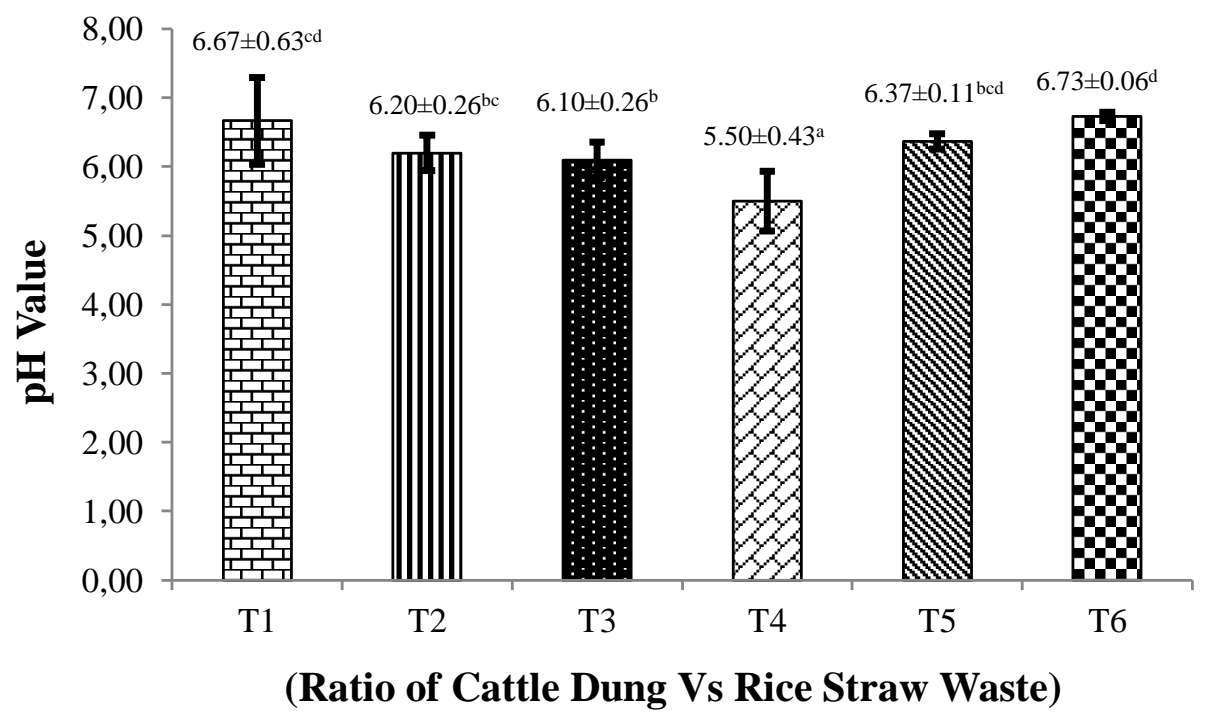

Figure 2. Comparison of $\mathrm{pH}$ values of compost in various treatment ratios of materials and Wrf (Ganoderma sp) bioactivator application. $\mathrm{T}_{1}(\mathrm{CD}: \mathrm{RS})(25 \%: 75 \%)+5 \%$ of Wrf; $\mathrm{T}_{2}$ (CD:RS)(50\%:50\%)+5\% of Wrf; $\mathrm{T}_{3}$ (CD:RS)(75\%:25\%)+5\% of Wrf; $\mathrm{T}_{4}$ (CD:RS) $(25 \%: 25 \%)+0 \%$ of Wrf; $\mathrm{T}_{5}$ (CD:RS)(50\%:50\%)+0\% of Wrf; $\mathrm{T}_{6}$ (CD:RS)(75\%:25\%)+0\% of Wrf; ${ }^{a, b, c, d}$ Different superscripts show significant differences $(\mathrm{p}<0.05)$; Fermentation time $=30 \mathrm{ds} ; \mathrm{CD}=$ Cow Dung; RS =Rice Straw; Wrf $=$ White rot fungus (Ganoderma $s p)$

\section{C-Organic}

The availability of organic material in compost was related to the element carbon.
This element was needed by plants as a source of energy to carry out life and growth activities. White rot fungus (Wrf) 
(Ganoderma sp) was a fungus type organism that was able to degrade lignin compounds from the wood. A description of the Corganic content of compost at various material ratios was presented in Figure 3.

The results of the ANOVA on the data in Figure 3 show that the application of Wrf bioactivators in the fermentation process had a very significant effect $(p<0.01)$ on the level of C-organic compost, however, differences in the ratio of materials (CD and $\mathrm{RS}$ ) and their interactions did not show a significant effect $(p>0.05)$. These results indicate that the Wrf (Ganoderma $s p$ ) bioctivator has the ability to degrade and remodel compounds contained in raw materials into organic compounds that can be utilized by plants. Based on Figure 3, it can be seen that the highest levels of $\mathrm{C}$ organic $(31.32 \% \pm 0.80)$ were obtained from the ratio (CD: $\mathrm{RS})(75 \%$ : $25 \%)$ by administering Wrf bioactivators $\left(\mathrm{T}_{3}\right.$ treatment). This ratio shows that the comparison of raw materials is very important and determines the final quality of compost.

The raw material (CD) was rich in nitrogen compounds $(\mathrm{N})$, whereas, RS was rich in carbon compounds $(\mathrm{C})$. Bioactivators play a role in overhauling compost raw materials by producing certain enzymes. This has a direct effect on the availability of carbon in compost (Wang et al., 2019; Wu et al., 2017).

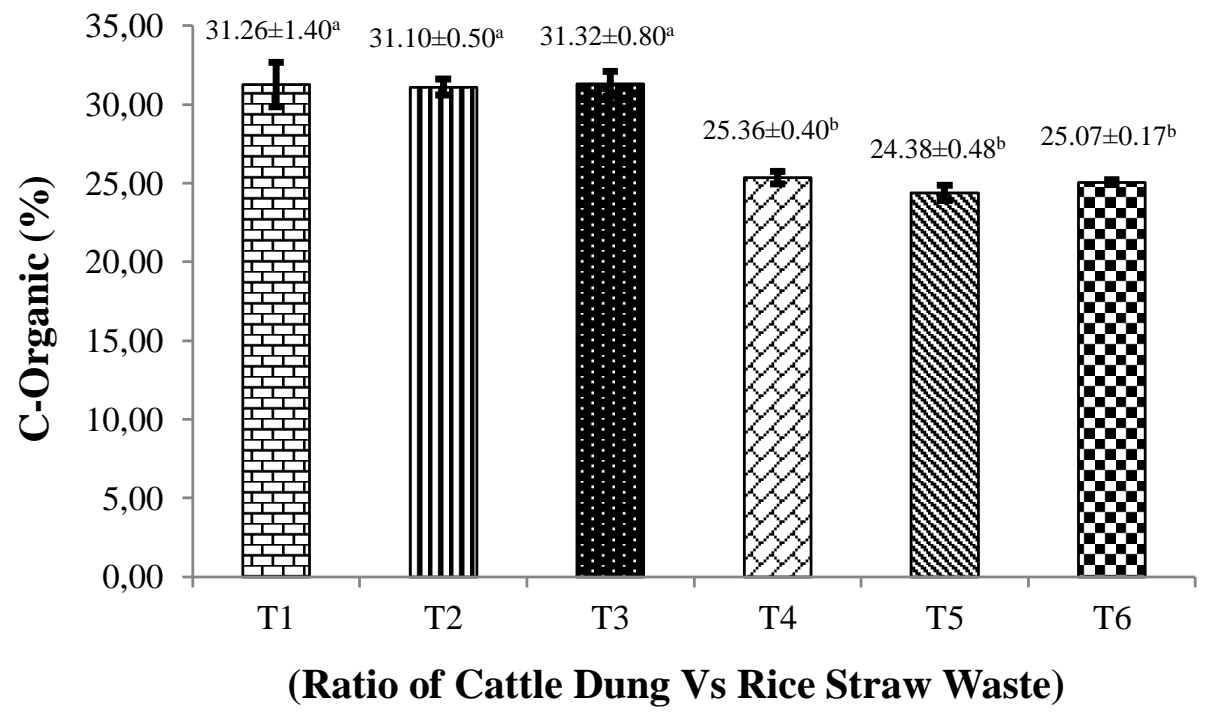

Figure 3. Comparison of C-organic of compost in various treatment ratios of materials and Wrf (Ganoderma sp) bioactivator application. $\mathrm{T}_{1}$ (CD:RS) $(25 \%: 75 \%)+5 \%$ of Wrf; $\mathrm{T}_{2}$ (CD:RS)(50\%:50\%)+5\% of Wrf; $\mathrm{T}_{3}$ (CD:RS)(75\%:25\%)+5\% of Wrf; $\mathrm{T}_{4}$ (CD:RS)(25\%: $25 \%)+0 \%$ of Wrf; $\mathrm{T}_{5}$ (CD:RS)(50\%:50\%)+0\% of Wrf; $\mathrm{T}_{6}$ $(\mathrm{CD}: \mathrm{RS})(75 \%: 25 \%)+0 \%$ of Wrf; Fermentation time $=30 \mathrm{ds} ; \mathrm{CD}=\mathrm{Cow}$ Dung; RS $=$ Rice Straw; Wrf $=$ White rot fungus (Ganoderma $s p$ )

\section{N-Organic}

$\mathrm{N}$-organic parameters are important in assessing the quality of compost. The availability of nitrogen $(\mathrm{N})$ in compost determines the quality of compost. The element nitrogen is the main ingredient needed by microorganisms to synthesize proteins. The characteristics of compost $\mathrm{N}$ organic from several different material ratios (CD and $\mathrm{RS}$ ) were presented in Figure 4. The results of the ANOVA on the data in Figure 4 show that the use of bioactivators and the difference in the ratio of material use (CD and RS) have a very significant effect $(\mathrm{p}<0.01)$ on the $\mathrm{N}$-organic value of compost. However, there was no significant interaction $(p>0.05)$ between the use of bioctivators with the ratio of material use. 
The data in Figure 4 shows that the Norganic value of the compost fermented using Wrf (Ganoderma $s p$ ) bioactivators $\left(\mathrm{T}_{1}, \mathrm{~T}_{2}\right.$ and $\left.\mathrm{T}_{3}\right)$ was on average higher than without Wrf $\left(\mathrm{T}_{4}, \mathrm{~T}_{5}\right.$ and $\left.\mathrm{T}_{6}\right)$. The results of the study generally showed that the $\mathrm{T}_{3}$ treatment produced the highest $\mathrm{N}$-organic value $(2.10 \% \pm 0.15)$, while the lowest value at the $\mathrm{T}_{4}$ treatment $(1.34 \% \pm 0.11)$. Based on the data, it is also seen that there is a tendency to increase the value of $\mathrm{N}$-organic with the increasing proportion of $C D$ use compared to the proportion of RS. This is caused by the activity of microorganisms that cause an increase in degradation.
Changes in the cycle of microorganisms largely determine the dynamics of mineralization and nutrition (Sileshi et al., 2017). In addition, the degradation process in the composting process causes the formation of $\mathrm{N}$-organic bioavailability (Zhu et al., 2019). The application of WRF bioactivators increases the proportion of $\mathrm{N}$ organic in compost. $\mathrm{N}$-organic donations are mostly obtained from the high proportion of $\mathrm{CD}$ in the mixture. This increase in N-organic will increase and improve the quality of compost as a provider of $\mathrm{N}$ compounds for bacteria to form proteins.

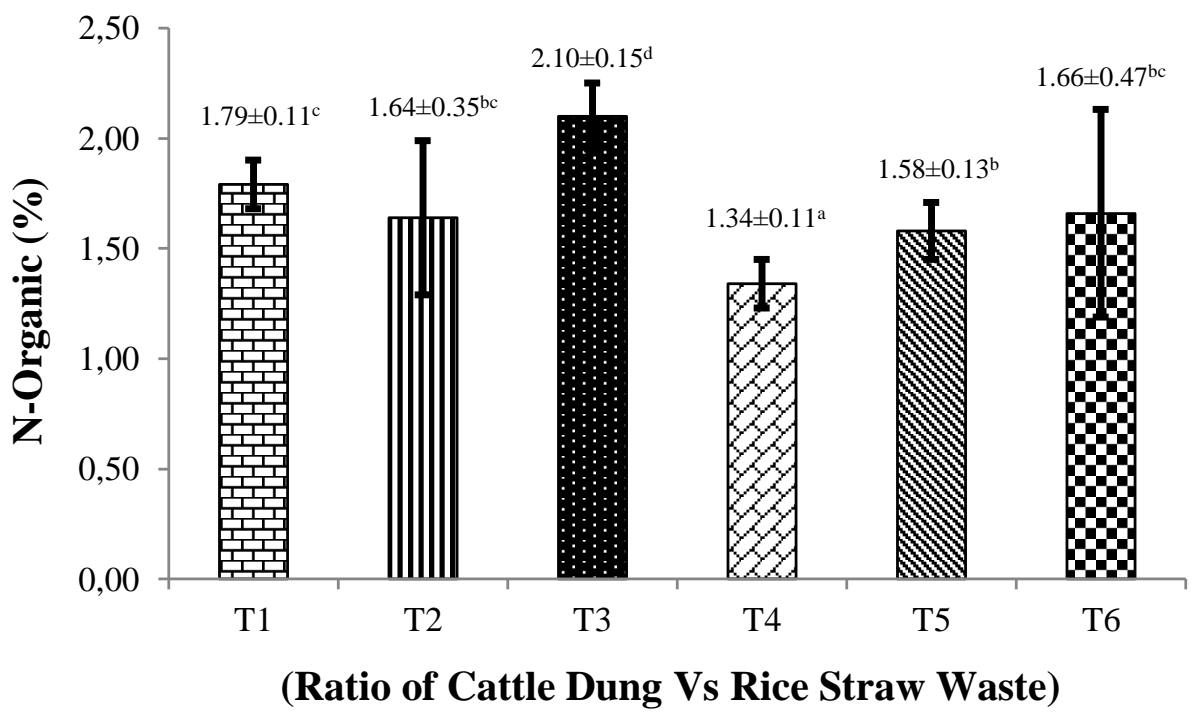

Figure 4. Comparison of N-organic of compost in various treatment ratios of materials and Wrf (Ganoderma $s p$ ) bioactivator application. $\mathrm{T}_{1}(\mathrm{CD}: \mathrm{RS})(25 \%: 75 \%)+5 \%$ of $\mathrm{Wrf}$; $\mathrm{T}_{2}$ (CD:RS)(50\%:50\%)+5\% of Wrf; $\mathrm{T}_{3}$ (CD:RS)(75\%:25\%)+5\% of Wrf; $\mathrm{T}_{4}$ (CD:RS)(25\%: $25 \%)+0 \%$ of Wrf; $\mathrm{T}_{5}$ (CD:RS)(50\%:50\%)+0\% of Wrf; $\mathrm{T}_{6}$ $(\mathrm{CD}: \mathrm{RS})(75 \%: 25 \%)+0 \%$ of Wrf; Fermentation time $=30$ ds; $\mathrm{CD}=\mathrm{Cow}$ Dung; RS $=$ Rice Straw; Wrf $=$ White rot fungus (Ganoderma $s p$ )

\section{$\mathrm{C} / \mathrm{N}$ ratio}

$\mathrm{C} / \mathrm{N}$ ratio value shows the comparison between $\mathrm{C}$ and $\mathrm{N}$ content in a media. The element carbon (C) is used by microorganisms as an energy source to produce the element nitrogen $(\mathrm{N})$. The $\mathrm{C} / \mathrm{N}$ ratio value of compost made from different raw material ratios (CD and $\mathrm{RS}$ ) were presented in Figure 5.

Statistically, using ANOVA, data in Figure 5 shows that the difference in the ratio of material use and interactions has a very significant effect $(\mathrm{p}<0.01)$ on changes in the $\mathrm{C} / \mathrm{N}$ ratio of compost. However, the difference in the use of Wrf bioactivators did not show any significance $(p>0.05)$. The availability of organic material in compost has a very important role. The carbon element in organic matter is utilized by microorganisms in bioactivators as an energy source. In general, the $\mathrm{C} / \mathrm{N}$ ratio obtained is in the range of $15.00 \pm 1.73$ - 
19.33 \pm 1.15 . Based on the standard requirements for compost $\mathrm{C} / \mathrm{N}$ ratio according to SNI 19-7030-2004 is $10-20$.
This shows that the $\mathrm{C} / \mathrm{N}$ ratio of compost produced is still in accordance with these requirements.

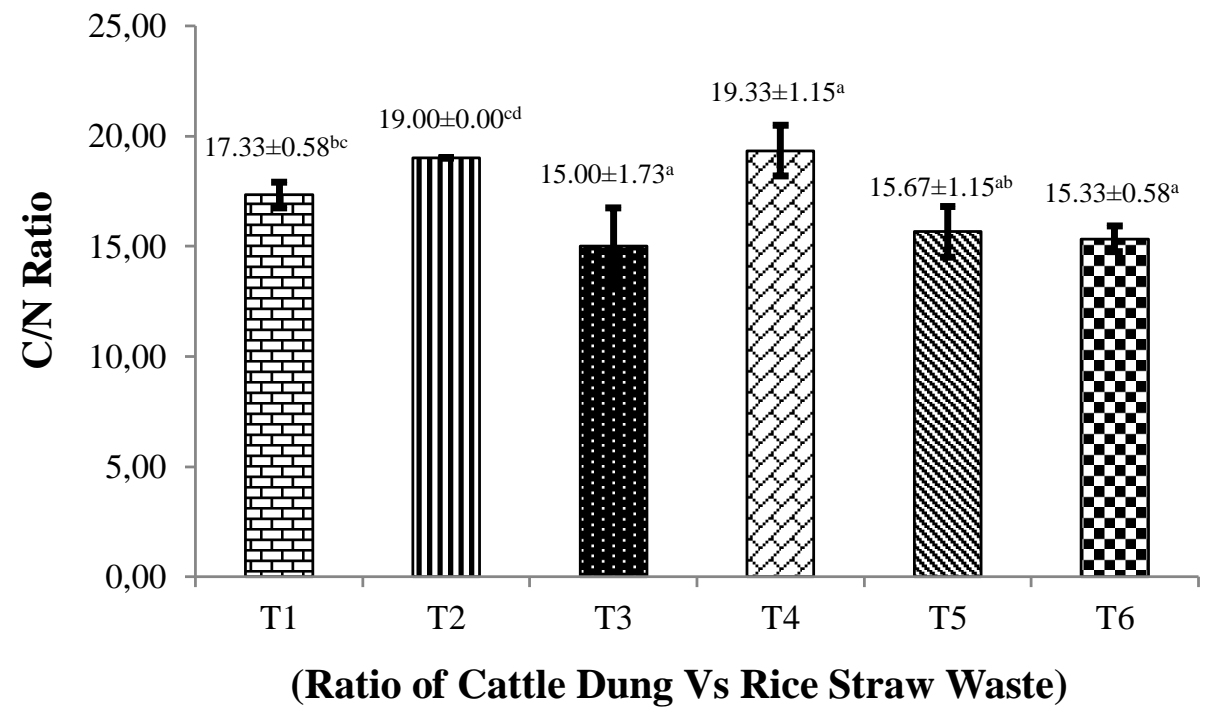

Figure 5. Comparison of $\mathrm{C} / \mathrm{N}$ ratio of compost in various treatment ratios of materials and Wrf (Ganoderma sp) bioactivator application. $\mathrm{T}_{1}(\mathrm{CD}: \mathrm{RS})(25 \%: 75 \%)+5 \%$ of Wrf; $\mathrm{T}_{2}$ $(\mathrm{CD}: \mathrm{RS})(50 \%: 50 \%)+5 \%$ of Wrf; $\mathrm{T}_{3} \quad(\mathrm{CD}: \mathrm{RS})(75 \%: 25 \%)+5 \%$ of Wrf; $\mathrm{T}_{4}$ $(\mathrm{CD}: \mathrm{RS})(25 \%: 25 \%)+0 \%$ of Wrf; $\mathrm{T}_{5}$ (CD:RS)(50\%:50\%)+0\% of Wrf; $\mathrm{T}_{6}$ $(\mathrm{CD}: \mathrm{RS})(75 \%: 25 \%)+0 \%$ of Wrf; ${ }^{\mathrm{a}, \mathrm{b}, \mathrm{c}, \mathrm{d}}$ Different superscripts show significant differences $(\mathrm{p}<0.05)$; Fermentation time $=30 \mathrm{ds} ; \mathrm{CD}=$ Cow Dung; RS =Rice Straw; $\mathrm{Wrf}=$ White rot fungus (Ganoderma $s p)$

According to Wang et al., (2019), compost with a $\mathrm{C} / \mathrm{N}$ ratio of 22 shows the most effective immobilization. The value of $\mathrm{C} / \mathrm{N}$ ratio of $15-27$ does not have a big influence on the quality of compost. The composting process is an attempt to reduce the value of the $\mathrm{C} / \mathrm{N}$ ratio of an organic material. The expected value is close to $\mathrm{C} / \mathrm{N}$ ratio of soil $(<20)$. The availability of $\mathrm{N}$ organic by microorganism activity was influenced by the $\mathrm{C} / \mathrm{N}$ ratio and $\mathrm{pH}$ (Zhu et al., 2019).

\section{CONCLUSION}

The application of Wrf (Ganoderma $s p$ ) bioactivators in the fermentation process of raw materials (CD and RS) significantly increases the value of $\mathrm{C}$-organic and $\mathrm{N}$ organic of compost, but does not show an effect on temperature, $\mathrm{pH}$ and $\mathrm{C} / \mathrm{N}$ ratio. The difference in the ratio of material use significantly increases the temperature, $\mathrm{N}$ organic as well as the $\mathrm{C} / \mathrm{N}$ ratio in compost. There is a positive interaction between the use of Wrf bioactivators with the ratio of material use (CD and $\mathrm{RS}$ ) to $\mathrm{pH}, \mathrm{N}$-organic and $\mathrm{C} / \mathrm{N}$ ratio of compost. The use of (CD:RS) ratio (75\%:25\%) fermented using Wrf bioactivators ( $\mathrm{T}_{3}$ treatment) produces the best compost characteristics compared to other treatments.

\section{Conflict of Interest}

There are no conflict of interest between researchers and the organizations or institutions that collaborate and are involved in this research.

\section{ACKNOWLEDGMENTS}

The research team would like to thank the Rector of Hasanuddin University and the Dean of the Faculty of Animal Science, Hasanuddin University, for the facilities 
provided. The research team specifically thanks to the student research team for their participation and cooperation in conducting the research.

\section{REFERENCES}

Agus, F. (2005). Petunjuk Teknis Analisis Kimia Tanah Tanaman Air dan Pupuk. Balai Penelitian Tanah.

Akdeniz, N. (2019). A systematic review of biochar use in animal waste composting. Waste Management, 88 , 291-300. https://doi.org/10.1016/j. wasman.2019.03.054

Chaudhry, A., Jilani, G., Khan, M., \& Iqbal, T. (2009). Improved processing of poultry litter reduces nitrate leaching and enhances its fertilizer quality. Asian Journal of Chemistry, 21, 49975003.

Chen, W., Liao, X., Wu, Y., Liang, J. B., Mi, J., Huang, J., Zhang, H., Wu, Y., Qiao, Z., Li, X., \& Wang, Y. (2017). Effects of different types of biochar on methane and ammonia mitigation during layer manure composting. Waste Management, 61, 506-515. https://doi.org/10.1016/j.wasman.201 7.01.014

Chen, Y., Liu, Y., Li, Y., Wu, Y., Chen, Y., Zeng, G., Zhang, J., \& Li, H. (2017). Influence of biochar on heavy metals and microbial community during composting of river sediment with agricultural wastes. Bioresource Technology, 243, 347-355. https://doi. org/10.1016/j.biortech.2017.06.100

Hsu, S.-F., \& Buckley, D. H. (2009). Evidence for the functional significance of diazotroph community structure in soil. The ISME Journal, 3(1), 124-136. https://doi.org/10.1038 /ismej.2008.82

Kaur, T., Brar, B. S., \& Dhillon, N. S. (2008). Soil organic matter dynamics as affected by long-term use of organic and inorganic fertilizers under maize-wheat cropping system. Nutrient Cycling in Agroecosystems,
81(1), 59-69. https://doi.org/10.1007/ s10705-007-9152-0

Leita, L., De Nobili, M., Mondini, C., Muhlbachova, G., Marchiol, L., Bragato, G., \& Contin, M. (1999). Influence of inorganic and organic fertilization on soil microbial biomass, metabolic quotient and heavy metal bioavailability. Biology and Fertility of Soils, 28(4), 371-376. https:// doi.org/10.1007/s003740050506

Ma, C., Hu, B., Wei, M.-B., Zhao, J.-H., \& Zhang, H.-Z. (2019). Influence of matured compost inoculation on sewage sludge composting: Enzyme activity, bacterial and fungal community succession. Bioresource Technology, 294, 122165. https://doi. org/10.1016/j.biortech.2019.122165

Mao, H., Lv, Z., Sun, H., Li, R., Zhai, B., Wang, Z., Awasthi, M. K., Wang, Q., \& Zhou, L. (2018). Improvement of biochar and bacterial powder addition on gaseous emission and bacterial community in pig manure compost. Bioresource Technology, 258, 195202. https://doi.org/10.1016/j.biortech .2018 .02 .082

Milinković, M., Lalević, B., JovičićPetrović, J., Golubović-Ćurguz, V., Kljujev, I., \& Raičević, V. (2019). Biopotential of compost and compost products derived from horticultural waste-Effect on plant growth and plant pathogens' suppression. Process Safety and Environmental Protection, 121, 299-306. https://doi.org/10.1016 /j.psep.2018.09.024

Morari, F., Vellidis, G., \& Gay, P. (2011). Encyclopedia of Environmental Health. In Encyclopedia of Environmental Health. Elsevier.

Nasution, D. (2020). Mentan Syahrul Targetkan 1 Juta Ternak Sapi Bali Tahun 2025.

Neugebauer, M., \& Sołowiej, P. (2017). The use of green waste to overcome the difficulty in small-scale composting of organic household waste. Journal of Cleaner Production, 156, 865-875. 
https://doi.org/10.1016/j.jclepro.2017. 04.095

Pandey, P. K., Cao, W., Biswas, S., \& Vaddella, V. (2016). A new closed loop heating system for composting of green and food wastes. Journal of Cleaner Production, 133, 1252-1259. https://doi.org/10.1016/j.jclepro.2016. 05.114

Philippot, L., Andert, J., Jones, C. M., Bru, D., \& Hallin, S. (2011). Importance of denitrifiers lacking the genes encoding the nitrous oxide reductase for $\mathrm{N} 2 \mathrm{O}$ emissions from soil. Global Change Biology, 17(3), 1497-1504. https:// doi.org/10.1111/j.1365-2486.2010.02 334. $\mathrm{x}$

Proietti, P., Calisti, R., Gigliotti, G., Nasini, L., Regni, L., \& Marchini, A. (2016). Composting optimization: Integrating cost analysis with the physicalchemical properties of materials to be composted. Journal of Cleaner Production, 137, 1086-1099. https:// doi.org/10.1016/j.jclepro.2016.07.158

Ratzke, C., \& Gore, J. (2018). Modifying and reacting to the environmental $\mathrm{pH}$ can drive bacterial interactions. PLOS Biology, 16(3), e2004248. https://doi. org/10.1371/journal.pbio.2004248

Said, M. (2014). By Product Ternak. In Teknologi dan Aplikasinya (pp. 98100). IPB Press.

Saputro, D., Wjaya, B., \& Wjayanti, Y. (2014). Pengelolaan limbah peternakan sapi untuk meningkatkan kapasitas produksi pada kelompok ternak patra sutera. Rekayasa, 12(2), 91-98. https://doi.org/10.15294/reka yasa.v12i2.10124

Sileshi, G. W., Nhamo, N., Mafongoya, P. L., \& Tanimu, J. (2017).
Stoichiometry of animal manure and implications for nutrient cycling and agriculture in sub-Saharan Africa. Nutrient Cycling in Agroecosystems, 107(1), 91-105. https://doi.org/10.10 07/s10705-016-9817-7

Steel, R. G., \& Torrie, J. (1991). Principle and Procedure of Statistics (2nd ed.). International Book Company.

Wang, L., Li, Y., Prasher, S. O., Yan, B., Ou, Y., Cui, H., \& Cui, Y. (2019). Organic matter, a critical factor to immobilize phosphorus, copper, and zinc during composting under various initial $\mathrm{C} / \mathrm{N}$ ratios. Bioresource Technology, 289, 121745. https://doi. org/10.1016/j.biortech.2019.121745

Wu, S., Shen, Z., Yang, C., Zhou, Y., Li, X., Zeng, G., Ai, S., \& He, H. (2017). Effects of $\mathrm{C} / \mathrm{N}$ ratio and bulking agent on speciation of $\mathrm{Zn}$ and $\mathrm{Cu}$ and enzymatic activity during pig manure composting. International Biodeterioration \& Biodegradation, 119, 429-436. https://doi.org/10.1016 /j.ibiod.2016.09.016

Zhang, J., Chen, G., Sun, H., Zhou, S., \& Zou, G. (2016). Straw biochar hastens organic matter degradation and produces nutrient-rich compost. Bioresource Technology, 200, 876883. https://doi.org/10.1016/j.biortech .2015 .11 .016

Zhu, L., Zhao, Y., Zhang, W., Zhou, H., Chen, X., Li, Y., Wei, D., \& Wei, Z. (2019). Roles of bacterial community in the transformation of organic nitrogen toward enhanced bioavailability during composting with different wastes. Bioresource Technology, 285, 121326. https://doi. org/10.1016/j.biortech.2019.121326 